\title{
Character Education: Analysis of Self-Regulated Learning on Systems Online Learning during the Covid-19 Pandemic
}

\author{
Triana Kartika Santi ${ }^{1}$, Riztika Widyasari ${ }^{2}$ \\ ${ }^{1,2}$ University of 17 Agustus 1945 Banyuwangi, Indonesia \\ trianasanti@untag-banyuwangi.ac.id
}

\begin{abstract}
The temporary closure of all educational institutions as an effort to prevent the spread of the Covid-19 outbreak worldwide has an impact on millions of students, including in Indonesia. The distance learning process (Online) is a learning solution during the pandemic which in its implementation has not been optimal as a whole. This adds to the obstacles in the application of learning methods because on one occasion there are too many learning loads that must be overcome by the teaching staff. This Writing Method Using descriptive. The main source of self-regulated formation is internal, meaning that it depends on the individual's actions, not on what other people do self-regulated formation is also inseparable from external factors, namely the environment. One study found that people with low self-regulation often experience negative emotions from people with high self-esteem. This can be interpreted that individuals will try to find symbols that can provide positive experiences and acceptance of a good environment. Online learning uses materials and timescales that are following the curriculum. The online learning method is here to change the conventional teaching style which can later improve work professionalism. Self-Regulation is a major influence on the formation of the character of students so that in achieving the formation of student character it is necessary to have SelfRegulated oriented learning. Character education during the pandemic is very different from its application in the conventional period because all learning is all digital (Online), therefore it is very difficult for students and lecturers to organize self-regulated learning processes. Character education is hampered by its value because student self-regulation is not organized, and affects student learning outcomes.
\end{abstract}

Keywords

character education; selfregulated learning; online learning

\section{Introduction}

At the end of 2019, various countries in the world and Indonesia in the February 2020 period were shocked by the Coronavirus outbreak or Covid-19 (Corona Virus Diseases-19). This virus originally existed and developed in Wuhan, China, and its transmission spread very quickly throughout the world. The World Health Organization (WHO), declared it a global pandemic. Many victims fell and died, including in Indonesia. The Indonesian government has launched the Large-Scale Social Restriction (PSBB) policy, a regulation issued by the Ministry of Health (Kemenkes) in the context of accelerating the handling of COVID-19, which is expected to be adhered to by the public. The PSBB rules are recorded in the Minister of Health Regulation Number 9 of 2020. All sectors have an extraordinary impact and in the end, jointly overcome in various ways so that transmission can be anticipated (Sri Sulasih, 2020). 
The temporary closure of all educational institutions as an effort to prevent the spread of the Covid-19 outbreak worldwide has an impact on millions of students, including in Indonesia (Sumantyo, 2020). Barriers to the teaching and learning process directly between teachers and students and the termination of learning assessments have an impact on the psychology of students, causing a decrease in the quality of skills. This burden is the responsibility of all elements of education, especially the government in facilitating the sustainability of schools for all stakeholders in the education sector (Syah, 2020). Various efforts have been made in the conditions and teaching situations at that time and after the Covid-19 pandemic. The government's efforts to organize and launch independent campuses for WFH (work from home) and SFH (study from home) or distance learning are efforts to reduce and overcome the spread of Covid-19 on campus and other educational places.

The distance learning process (Online) is a learning solution during the pandemic which in its implementation has not been optimal as a whole. Some things must be considered in this distance learning, among others, the quality of student resources must be improved, both in terms of content and methodology as well as in terms of the use of information technology. In addition, students are also less than optimal in participating in distance learning, both due to an unstable internet network or in terms of providing a limited internet quota (Aqib and Khoiriyah, 2020). It is undeniable that distance learning (PJJ) during the COVID-19 pandemic has caused various responses and changes to the learning system that can affect the learning process and the level of development of students in responding to the material presented (Basar, 2021). It is important to analyze student self-regulation in the learning process because it affects learning outcomes and assessments. Self-regulated learning is an individual's ability to learn using various aspects such as motivation, metacognition, and behavior as well as possible through beliefs and his way of directing himself to achieve the goals that have been set.

Distance Learning or PJJ is a new learning method for university students during the Covid-19 pandemic. Based on the Decree of the Head of the Education Office Number 467 of 2020 concerning the Education Calendar for the 2020/2021 Academic Year and Readiness to Start Teaching and Learning Activities. During the pandemic, learning and teaching activities are carried out through the PJJ method following the Joint Decree (SKB) of 4 Ministers and the Decree of the Task Force for the Acceleration of Handling Covid-19. This adds an obstacle in the application of learning methods because on one occasion there are too many learning burdens that must be overcome by the teaching staff, namely the mastery of various variations of methods and various variations of technology without the support of good internet data, the learning will be hampered (Angga, 2020). Meanwhile, most universities use the Zoom meeting application as an alternative to distance learning.

Zoom meeting is an application that provides conference services or remote meetings with the concept of screen sharing. This application is not only capable of one video call but is capable of calling group calls of up to 100 participants. Zoom has basic features, namely up to 100 participants with a meeting time of 40 minutes which can be obtained for free, to enjoy more features that can be subscribed to with Zoom Business (Angelina and Rahadi, 2020). This learning process is generally experienced throughout the University. Self-regulated learning is an individual's ability to learn using various aspects such as motivation, metacognition, and behavior as well as possible through beliefs and his way of directing himself to achieve the goals that have been set. 


\section{Research Methods}

This writing method is descriptive. The descriptive method according to Sugiono (2009) is a method that aims to describe or provide an overview of the object under study through data or samples that have been collected as they are without analyzing and making conclusions that apply to the public. In other words, analytical descriptive research takes problems or focuses on problems as they are when the research is carried out, the results of the research are then processed and analyzed to conclude.

\section{Results and Discussion}

\subsection{Factors Affecting Self-regulated}

\section{a. Environmental Factors}

Although the main source of self-regulated formation is internal, meaning that it depends on the individual's actions, not on what others do self-regulated formation is also inseparable from external factors, namely the environment. According to Egan (1976 in Kelley, 1979), individuals perceive themselves through feedback from others and observations of the consequences of their actions. In line with the process of maturity, family, friends, and society in general also instill values and norms that apply so that individuals are judged based on these norms. According to Fuhrmann (1990), individuals learn to evaluate themselves according to the results of the totality of interactions and experiences that occur to them. Environmental acceptance of individuals will affect the formation of self-regulation. The process of perceiving experience occurs simultaneously with the process of meaning and assessment of the environment. Unconsciously, personal experiences that have been perceived by individuals in the past will influence them to assess, perceive, and determine their existence. Experiences that are perceived as positive or pleasant experiences will make individuals tend to view themselves as competent in facing life's challenges, which in turn will form self-efficacy in individuals. Self-respect is formed when an individual is treated with respect by others in his environment, has a high and satisfying experience of interacting with others, so he feels confident that he is useful and meaningful to others.

\section{b. Emotional Factors}

There is a two-way relationship between self-regulated ways of thinking and emotional appreciation. Self-regulation is also called a generator that affects the way individuals think and experience emotions. High self-regulation will produce more positive emotions, such as a sense of comfort and happiness for what is in him. Positive emotions will make it easier for individuals to believe in their abilities and worth, which will strengthen their self-regulation. Low self-esteem will produce more negative emotions, such as anger, disappointment, fear, and hopelessness, which will increase self-doubt and weaken self-regulation (Branden, 1994). High self-regulation will increase positive effect by providing academic improvement and fighting other negative emotions and by increasing self-adjustment, while low self-regulation is associated with chaotic learning frames, anxiety, and decreased learning achievement. One study found that people with low self-regulation often experience negative emotions from people with high self-esteem (Cutrona, 1982; Goswick and Jones, 1981; Leary, 1983; Taylor and Brown, 1988; White, 1981). in Hogg and Vaughan, 2002). Based on the explanation above, individuals will evaluate themselves according to the totality of interactions and experiences that occur to them, where environmental acceptance of individuals will affect the formation of self- 
regulation, especially in adolescents. High self-regulation is formed because of the experiences they have and the acceptance of the environment towards them is very positive. Vice versa. This can be interpreted that individuals will try to find symbols that can provide positive experiences and acceptance of a good environment.

From the explanation above, it is stated that several indicators in achieving selfregulated formation are part of the values in character building, because that is why character building requires increasing student self-regulation in the learning process. So that this will be a synergy of common goals in learning that carries the mission of building student character. The solution is that learning must be oriented towards self-regulated values in character building. The pandemic has made everything digital (online), students and lecturers have difficulty providing a stimulus to self-regulation, this is because face-toface efforts are not possible, given the common interests related to health protocols.

\subsection{Character Education: Learning during the Pandemic}

COVID-19 Pandemic is changing the social order of society into external factors that affect the current learning process. Physical restrictions and social activities on a large scale do not allow learning to be carried out face-to-face, so that it has a major impact on learning activities that must be carried out practically. Practical learning is more dominant in special places such as laboratories. Psychomotor abilities are needed in this practical learning. One of the practical lessons that have been impacted by the COVID-19 pandemic is scientific lectures. As a branch of science whose development and application of knowledge requires the results of experimental work with certain standards, learning cannot be done only by providing theoretical material. With the enactment of health protocols during the pandemic, laboratory practicums cannot be carried out as they should. On the other hand, this practicum activity cannot be simply eliminated so that it is in line with the nature of the learning itself.

Online learning uses materials and timescales that are following the curriculum. As for the place, online learning has the flexibility of learning time, you can study anywhere and anytime. This is because it is quite difficult to implement health protocols on campus, so online learning is a pretty good alternative during a pandemic like this. Online learning provides benefits for both lecturers and students. For students, online learning is an alternative method of learning that does not require them to be present in class. In addition, this learning will form a spirit of independent learning, and also encourage interaction between students, especially for students who are usually not actively speaking, so they will be able to more freely express their opinions/questions via writing if online learning is carried out as it is today. As for lecturers, online learning methods are here to change conventional teaching styles which can later improve work professionalism. The online learning model also provides opportunities for lecturers to assess and evaluate the learning progress of each student more efficiently because they can interact directly and have a track record.

The success of learning media is not only seen from a technical side but also depends on the characteristics of each student revealed that all the literature on e-learning indicated that not all students would be successful in online learning. This is due to the learning environment, and the characteristics of each online student (Hakim, Sinar Ikrar Prihatanto, \& Rusli, 2019). Online learning at each University applies different forms and techniques. As for the output, many students feel that they do not understand the material, have more independent assignments, and have difficulty doing practicum as supporting courses. Practicums conducted online sometimes cannot be practiced at home due to limited tools and experimental samples. Lecturers are also more difficult to supervise students during 
online learning because it is limited to the media. Learning experiences are a series of student activities carried out to obtain information and competencies following the objectives to be achieved (Sari, 2018). This is certainly a new experience for students to receive practicum material online (online), so that the online learning process (online) forms a new learning experience.

The learning experience will not be separated from a learning process that is owned by a person because the learning experience will make it easier for someone to understand the lesson or knowledge to be studied and can affect learning outcomes, because the experience that has been owned will be used in the final stage of learning, namely the exam. So that the better the learning experience will have good implications for individual achievement (Efendi, Sandayanti, \& Hutasuhut, 2020)

\subsection{Analysis of Character Building Character}

building for the current generation is one of the goals of national education, in the objectives of the National Education System Number 20 of 2003 it is explained that, Education is a conscious effort in structurally creating a learning atmosphere and learning process so that students actively develop their potential so that they have a basic character that is based on religious-spiritual strength, self-control, personality, intelligence, noble character, and social skills for themselves, society, nation, and state. The macro objective of National Education Integration is education based on Pancasila and the 1945 Constitution of the Republic of Indonesia which is based on religious values, Indonesian national culture and is sensitive to the demands of changing times. Students in this case have the task of developing their potential through the learning process available at certain paths, levels, and types of education. This polemic has become a contemporary problem in the millennial era and has even become a common demand in educational goals.

This is the government's response in dealing with it. The government has reissued the Presidential Regulation of the Republic of Indonesia No. 87 of 2017, confirming that the purpose of strengthening character formation is to shape students to be good, have good morals, and have good character. Presidential Decree No. 87 of 2017 has been issued by the President of the Republic of Indonesia regarding Strengthening Character Education in the hope of being able to overcome the problems faced by the current generation. This alarming condition requires solutions both at the internal and external levels regarding character formation, so it requires special support to the community and educators in developing the character of students (Hadisi, 2015).

The Ministry of National Education (2011) describes the matter of character building through educational institutions that in the process of implementing it design students to have a caring and responsible mentality. This opinion shows that character formation is related to innate, heart, soul, personality, character, behavior, personality, character. , character, temperament, character. Another opinion was expressed that character formation is "a system of inculcating character values to school members which includes components of knowledge, awareness or willingness and action to implement these values." so that the formation of character in schools, must involve all components (educational stakeholders) including the components of education itself, namely curriculum content, learning and assessment processes, handling or management of subjects, school management, implementation of extracurricular activities or activities, empowerment of infrastructure, financing and the work ethos of all school/environmental residents (Royzah, 2016).

Another meaning is that the formation of character is a unity of personality goals. The essence of this opinion is that character formation refers to a series of attitudes, behaviors, motivations, and skills. Sudarajat (2010) argues that "character formation has 
the same essence and meaning as moral education and moral education which aims to shape children's personalities, so that they become good human beings, citizens, and good citizens." These two opinions show that the notion of character refers to a series of attitudes. Based on this opinion, it can be emphasized that character building is an effort that is designed and implemented systems to help students understand the values of human behavior related to God Almighty, oneself, fellow human beings, the environment, and nationality which is manifested in thoughts, attitudes, feelings, words, and actions based on religious norms, laws, manners, culture, and customs in the nation and state (Wening, 2012a).

National character is an important aspect of the quality of human resources because the quality of the nation's character determines the progress of a nation. Quality characters need to be formed and nurtured from an early age. Early age is a critical period for the formation of one's character. Without avoiding the possibility of other factors that can influence the next generation of the nation to carry out various types of actions that deviate and are very far from the values that develop in Indonesian society in general, one of which is globalization. The factor of globalization that brings the flow of information so that it is difficult to contain it is felt to have a very large contribution to the various cases that befell the next generation of the nation. Erikson (1968) according to Freud, failure to cultivate a good personality at an early age will form a person who has problems in later adulthood. The success of parents in guiding their children in overcoming personal conflicts at an early age will determine the success of children in social life in later adulthood (Wening, 2012b).

Efforts to stem or minimize the development of the flow of globalization can be carried out through education channels whose learning is oriented towards self-esteem to foster character formally and informally to instill values that can become the inspiration of the nation's next-generation without having to be immersed in the flow of globalization which has an impact. negative for their lives.

The chairman of the MPR, Mr. Zulkifli Hasan, thinks that the era of globalization does not all bring positive effects, but there are also negative ones. Therefore, character building is very important to counteract the negative impacts of globalization in Indonesia. "Amid an unstoppable global influence, of course, there are also many negative impacts," this was conveyed at The Third International Conference-Thoughts on Human Sciences in Islam (IC-Thusi) event at the Parliament Complex, Senayan, Jakarta, Wednesday (16 /11/2016). The development of the nation's character, among others, building social ethics, is important to build this negative impact, "character formation will enlighten the concept of free will by balancing the concept of determinism, in practical education. Education must provide a wide space for students as the nation's next-generation to choose.

Education emphasizes that freedom is a package with responsibilities that must be borne. If there is an error in making a choice. When contrary to ethics and universal norms. Responsibilities and witnesses must be accepted gracefully. So that the next generation of the nation can recognize and be responsible for choosing and willing. Theoretically, character education provides fresh air for the future generations of the nation. With the formation of character, all things caused by globalization that lead in a negative direction can be minimized. The formation of learning characters will instill the values of national character which have been the identity of the Indonesian nation (Rudiana, 2017).

The values of national character that are meant include religious values. Honest. Tolerance. Discipline. Hard work. creative. Independent. Democratic. Curiosity. Spirit of nationality. Love the homeland. Appreciate achievements. Friendship. Love peace. Love to read. Care for the environment, care for social and responsibility (Ministry of National 
Education. 2012) The implementation of the values of character education can be carried out through a process of empowerment and civilizing as outlined as one of the principles of organizing national education. This process takes place in three pillars of education, namely: in 1) schools. The implementation of learning in schools is developed through learning experiences and learning processes that lead to the formation of character in students. Character formation in teaching and learning activities in the classroom. Implemented using an integrated approach in all subjects. 2) family. Family is the most important thing in the formation of children's character. Because the family is like the root that determines what and how an individual will become if the family carries out its functions properly, then the individuals who are born will have good morals and character. So that it can form quality human resources. 3) community. Cultivation in the community can be done through the example of community leaders. Habituation of values in the community. Fostering the development of a relationship with God Almighty. Enforcement of applicable rules (Darsiharjo, 2013).

Thus the role of character formation is very important to stem the flow of information in the era of globalization which has an impact on the erosion of the nation's character which is marked by various cases that are stored in social life, especially cases carried out by the next generation of the nation. Learning character building will educate the next generation of the nation either directly or indirectly from the previous three pillars, namely in the school environment, community, and in the family to know their identity as the next generation of the Indonesian nation that has a national character as mandated by the government. So that various deviant cases committed by the younger generation in the family, school, and community environment can be minimized.

\section{Conclusion}

Self-Regulated has a major influence in the formation of the character of students so that in achieving the formation of student character it is necessary to have learning oriented self-regulated. Learning is a bridge for the growth of the character of students. If one of these learnings does reflection self-regulated that is able to grow student academic achievement, the process of character building is very necessary. This is because the formation of character enhancement is very difficult in national education if learning is not oriented towards certain values. Character education during the pandemic is very different from its application in the conventional period, because all learning is all digital (Online), therefore it is very difficult for students and lecturers to organize self-regulated learning processes. Therefore, self-regulation is very influential during a pandemic. Character education is hampered in value because student self-regulation is not organized, and affects student learning outcomes.

\section{References}

Ali, M. (2013) 'Implementasi Kurikulum Pendidikan Nasional 2013', Jurnal Pedagogi, 2(2), pp. 49-60.

Angelina dan rahadi. (2020). STRATEGI PENGELOLAAN ZOOM MEETING DALAM PROSES. Jurnal Pendidikan Teknologi Informasi (JUKANTI), 3(2621-1467), $27-$ 32.

Angga, N. M. (2020). Hubungan Pemilihan Teknologi dan Pencapaian Kompetensi dalam Metode Pembelajaran Daring. KELUWIH: Jurnal Sains Dan Teknologi, 1(2), 92-98. https://doi.org/10.24123/saintek.v1i2.2956 
Angga, N. M. (2020). Hubungan Pemilihan Teknologi dan Pencapaian Kompetensi dalam Metode Pembelajaran Daring. KELUWIH: Jurnal Sains Dan Teknologi, 1(2), 92-98. https://doi.org/10.24123/saintek.v1i2.2956

Aqib, M. A., \& Khoiriyah, M. (2020). Analisis Kepuasan Mahasiswa Terkait Kinerja Pembelajaran Daring oleh Dosen Via Aplikasi Whatsapp Grup. Indonesian Journal of Humanities and Social Sciences.

Basar, A. M. (2021). Problematika Pembelajaran Jarak Jauh Pada Masa Pandemi Covid19. Edunesia: Jurnal Ilmiah Pendidikan, 2(1), 208-218. https://doi.org/10.51276/edu.v2i1.112

Branden, N. (1994). The Six Pillars of Self- Esteem, United States of America: Bantam Books.

Darsiharjo (2013) 'Pembentukan Karakter Bangsa Pada', Geoedukasi, 2(1), pp. 1-5.

Efendi, D. H., Sandayanti, V., \& Hutasuhut, A. F. (2020). Hubungan Efikasi Diri Dengan Regulasi Diri Dalam Belajar Pada Mahasiswa Fakultas Kedokteran Universitas Malahayati. Anfusina: Journal of Psychology. https://doi.org/10.24042/ajp.v3i1.6046

Fuhrmann, B.S. (1990). Adolesences, England: A Division of Scott Foresman and Company.

Gray, A. (1997). Indigenous Rights and Development: Self-Determination in an Amazonian Community, Oxford: Berghahn Books. Grubb.

Hadisi, L. (2015) 'Pendidikan Karakter Pada Anak Usia Dini', Al-Ta'dib.

Hakim, L., Sinar Ikrar Prihatanto, F., \& Rusli, M. (2019). Pengalaman Belajar Mahasiswa Kedokteran Dalam Penggunaan Rekaman Kuliah Sebagai Media Pembelajaran. Jurnal Pendidikan Kedokteran Indonesia: The Indonesian Journal Of Medical Education. Https://Doi.Org/10.22146/Jpki.31297

Hogg, M.A. \& Vaughan, G.M. (2002). Social Psychology (3rd ed), London: Prentice-Hall.

Kelley, H.H. (1979). Attribution Theory in Social Psychology, Lincoln: University of. Nebraska Press. Pembelajaran Daring. KELUWIH: Jurnal Sains Dan Teknologi, 1(2), 92-98. https://doi.org/10.24123/saintek.v1i2.2956 royzah. (2016). ARTIKEL PENDIDIKAN KARAKTER.pdf.

Rudiana. (2017). Pendidikan Karakter dalam Budaya Popiler. Jurnal Mutiara Pedagogik, 2(1), 1-14.

Sari, Anggita Gardeesna \& Muhartono (2018) Pengalaman Belajar Mahasiswa Fakultas Kedokteran Universitas Lampung pada Blok Emergency Tahun 2018. Journal Majority Vol;7.No:3 2018 Doi.Org/10.12152/Jpki.15301

Sri Sulasih, E. (2020). Ketidakefektifan Penerapan Pembatasan Sosial Berskala Besar (PSBB) di Daerah Khusus Ibukota Jakarta. Binamulia Hukum, 9(1), 67-82. https://doi.org/10.37893/jbh.v9i1.104

Sumantyo, F. D. S. (2020). Pendidikan Tinggi di Masa dan Pasca Covid-19. Jurnal Kajian Ilmiah, 1(1), 81-92. https://doi.org/10.31599/jki.v1i1.266

Syah, R. H. (2020). Dampak Covid-19 pada Pendidikan di Indonesia: Sekolah, Keterampilan, dan Proses Pembelajaran. Salam: Jurnal Sosial Dan Budaya Syar-I, 7(5). https://doi.org/10.15408/sjsbs.v7i5.15314

Syah, R. H. (2020). Dampak Covid-19 pada Pendidikan di Indonesia: Sekolah, Keterampilan, dan Proses Pembelajaran. SALAM: Jurnal Sosial Dan Budaya Syar-I, 7(5). https://doi.org/10.15408/sjsbs.v7i5.15314

Wening, S. (2012a). Pembentukan Karekter Bangsa Melalui Pendidikan Nilai. Jurnal Pendidikan Karakter, II(1), 55-66. https://doi.org/10.21831/jpk.v0i1.1452

Wening, S. (2012b). The nation's character building through value education. Jurnal Pendidikan Karakter, II(1), 55-66. 